\title{
EXPLAINING AFRICAN PARTICIPATION IN INTERNATIONAL COURTS
}

\author{
PETER BRETT AND LINE ENGBO GISSEL*
}

\begin{abstract}
Africa has more international courts than any other continent. Yet international relations scholarship has failed to explain this African move to law. This article does so using Bayart's concept of extraversion. It shows how the creation of international courts in the 1990s and early 2000s was the result of extraverted strategies for attracting international resources and pre-empting donor pressures for political and legal reforms. By adopting these strategies, African states failed to behave in the 'strategic' manner anticipated by both constructivist and liberal institutionalist international relations theory. International court creation did not reflect the pursuit of national interests or a response to normative NGO pressures. Making this argument, the article analyses the design and ratification of two new international courts: the SADC Tribunal and International Criminal Court. Using the case studies of Zimbabwe and Kenya, it shows how global scripts were repeated by even those states which have, in recent years, most vocally asserted their national interests against these courts.
\end{abstract}

... We are an outward reaching country, not inwards [looking]. We still think we can learn from others, notwithstanding that there can be unforeseen consequences... Mutula Kilonzo, Minister of Justice and Constitutional Affairs, explaining why Kenya ratified the Rome Statute. Nairobi, 9 May 2011

\footnotetext{
${ }^{*}$ Peter Brett is Lecturer in African Politics at the School of Politics and International Relations, Queen Mary University of London. Line Engbo Gissel is Assistant Professor at the Department of Social Sciences and Business, Roskilde University. The authors wish to thank the participants in the panel on 'Courts in Non-Democratic Systems, Democratisation and Democratic Breakdown' at the 2013 ECPR General Conference in Bordeaux for insightful comments on a much earlier version of this article. They are also grateful to the reviewers and editors of African Affairs for numerous suggestions that helped improve it. Needless to say, however, all errors remain their own.
} 
AFRICAN STATES HAVE TO A GREATER EXTENT than other world regions formally judicialised their political affairs. ${ }^{1}$ When the Cold War ended, sub-Saharan Africa had only one permanent international court (IC): the inoperative Court of Justice of the Economic Community of Central African States. By 2004 it had nine ICs, more than any other continent. ${ }^{2}$ By comparison, Europe has six, Latin America five, and Asia one. At the same time, African states make up the largest regional bloc in the Assembly of States Parties of the International Criminal Court (ICC) and were among the first states to ratify the ICC treaty. Temporary international war crimes tribunals, such as the International Criminal Tribunal for Rwanda and Special Court for Sierra Leone, have also emerged after conflicts.

International relations theorists have struggled to account for this African enthusiasm for ICs. Karen Alter, whose recent account is the most systematic, admits to having 'no good explanation' for it. ${ }^{3}$ Cesare Romano's recent survey of the topic also fails to account for African states' practices. ${ }^{4}$ This article, by contrast, proposes an answer. Rejecting the two most prominent theories of international judicialisation - liberal institutionalism and constructivism - it argues that Africa's many international courts should be understood as an example of legal 'extraversion. ${ }^{5}$ It was part of African states' broader response to the particular international pressures and financial constraints of the post-Cold War period. This argument is based on the in-depth analysis of two case studies: Zimbabwe's support for establishing the Southern African Development Community (SADC) Tribunal and Kenya's support for creating the ICC.

\footnotetext{
${ }^{1}$ We refer here narrowly to 'constitutive judicialisation': the creation, not use, of new courts. Lars Blichner and Anders Molander, 'Mapping Juridification', European Law Journal 14, 1 (2008), p. 41.

${ }^{2}$ These now included the Court of Justice of the African Economic Community (1991), the Court of Justice of the West African Economic and Monetary Union (1996), Common Court of Justice and Arbitration of L'Organisation pour l'Harmonisation en Afrique du Droit des Affaires (1997), Court of Justice of the Common Market for Eastern and Southern Africa (1998), Court of Justice of La Communauté Economique et Monétaire de l'Afrique Central (2000), the Southern African Development Community Tribunal (2000), East African Community Court of Justice (2001), Court of Justice of the Economic Community Of West African States (2001), and African Court on Human and People's Rights (2004). See Cesare Romano, Karen Alter and Yuval Shany (eds), The Oxford University Press handbook of international adjudication (Oxford University Press, Oxford, 2014).

${ }^{3}$ Karen Alter, The new terrain of international law: Courts, politics, rights (Princeton University Press, Princeton, NJ, 2014), p. 153.

${ }^{4}$ Cesare Romano, 'The shadow zones of international judicialization' in Romano, Alter and Shany (eds), The Oxford University Press handbook, pp. 98-9.

5 Jean-François Bayart, 'Africa in the world: A history of extraversion', African Affairs 99, 395 (2000), pp. 217-67; The State in Africa: The politics of the belly (Polity, Cambridge, 2009).
} 
Our two case studies were selected for being representative and 'crucial.' ${ }^{6}$ They relate to a regional and a global IC, which together represent the landscape of African judicialisation: most African ICs are regional in nature, while most African states have joined at least two global ICs. The country selection stems from Zimbabwe and Kenya's recent roles in initiating political backlashes against the ICs: Zimbabwe co-ordinated a successful roll back of the SADC Tribunal's human rights jurisdiction, while Kenya orchestrated a vocal African critique of the ICC. These developments make Zimbabwe and Kenya the most likely cases for a successful test of the mainstream explanations for international judicialisation. Liberal institutionalism stresses the importance of domestic politics; since the recent political backlashes signify the salience of domestic concerns, we should expect to see their influence on court design. Constructivism emphasises norm internalisation and civil society persuasion; given the assertive NGO sector in these two countries, we should expect to find its mobilisation helping explain court ratification. If these two most prevalent theories of court creation have their expectations disappointed in Kenya and Zimbabwe, then they are unlikely to explain other African cases.

Data for the case studies derive from interviews, parliamentary and UN research, and the relevant 'grey' literature. Interviews were conducted in Nairobi in April and May 2011, and in Windhoek, Johannesburg and Harare in August and September 2011 and April 2012. Where relevant, regional data is included to show how our cases exemplify broader trends.

The article begins by mapping the proliferation of African international courts. Thereafter it examines mainstream international relations explanations for the creation of international legal regimes, relating them to important assumptions made by the specialist literature on Africa's ICs. It then introduces and clarifies our understanding of the 'extraversion' concept, situating it within recent debates about African agency in international relations. This clarified concept is then used, finally, to analyse our two cases.

\section{The proliferation of African international courts}

Africa now has the most regional ICs, and all but two African states are part of a regional judicial system. Furthermore, with the exception of Europe, the world's four global ICs cover more of

\footnotetext{
${ }^{6}$ John Gerring, Case study research: Principles and practices (Cambridge University Press, Cambridge, 2007), pp. 912 and $120-1$.
} 
Africa than they do of other regions: the International Court of Justice includes all African states, the International Tribunal for the Law of the Sea 83 percent, the World Trade Organisation Appellate Body 80 percent, and the ICC 63 percent.

This shift is part of a global turn to law: of the world's 26 permanent, operational international courts, 19 were established after $1989 .^{7}$ Africa's international courts also reflect the global postCold War trend of granting access to non-state actors and making jurisdiction compulsory. ${ }^{8}$ Seven of the 16 permanent international courts with private litigant initiation rights are located in Africa. ${ }^{9}$ These new design features '[undermine] a government's ability to block inconvenient legal suits from proceeding,' and thus represent the possibility of judicial independence from politics. ${ }^{10}$ Table 1 below summarises Africa's international judicialisation.

\footnotetext{
${ }^{7}$ Alter, The new terrain, pp. 73-5.

${ }^{8}$ See Ibid., pp. 81-5; Alexandra Harrington 'Don't mind the gap: The rise of individual complaint mechanisms within international human rights treaties,' Duke Journal of Comparative and International Law 22, 153 (2012), pp. 153-82.

${ }^{9}$ Alter, The new terrain, p. 84.

${ }^{10}$ Ibid., p. 83.
} 


\begin{tabular}{llll}
\hline Date of & Issue area & Individual access & Compulsory \\
& establishment & jurisdiction \\
& (operational date) &
\end{tabular}

\section{Regional ICs}

1 Court of Justice of the $1993(2001)$

Economic Community of

West African States

2 International Criminal

3 Court of Justice of the West 1994 (1996)

African Economic and

Monetary Union

4 Court of Justice of the

Common Market for Eastern

and Southern Africa

5 Common Court of Justice and 1995 (1997)

Arbitration of L'Organisation

pour l'Harmonisation en

Afrique du Droit des Affaires

$6 \quad$ African Court on Human and 1998 (2006)

Human rights

People's Rights

$7 \quad$ Court of Justice of La

Communauté Economique et

\section{No, but independent Yes}

prosecutor

Yes

Yes, with optional

protocol

Yes, with optional

protocol 
Monétaire de l'Afrique

Central

8 East African Community Court of Justice

9 The Southern African Development Community Tribunal

10 Special Court for Sierra Leone

$$
1999 \text { (2001) }
$$

$2000(2007)$

2002 (2002)

Atrocity

governance

Economic

Yes, after exhausting

domestic remedies

No, but independent

prosecutor

\section{Global ICs}

1 International Court of Justice 1945 (1946)

Inter-state relations

Maritime relations

No

No

No

Yes

No, but independent

No

No

Trade

Atrocity

\section{prosecutor}

Sources: African International Courts and Tribunals, http://www.aict-ctia.org/ (3 May 2016); James T. Gathii, ‘The under-appreciated jurisprudence of African regional trade judiciaries', Oregon Review of International Law 12 (2010), pp. 245-82; Cesare Romano, Karen Alter and Yuval Shany (eds), The Oxford handbook of international adjudication (Oxford University Press, Oxford, 2015). 
Over the last 20 years, international relations research on legal regimes has been characterised by the emergence, and, more recently, convergence, of two significant research agendas: liberal institutionalist and constructivist. Each shares important assumptions with a particular strand of the specialist literature on African ICs. Liberal institutionalism begins from the assumption that states are rational utility-maximising entities. Such states seek to ensure a correspondence between their legal commitments and their national interests. This generates a puzzle: why would states create international courts, given the corresponding loss of control and sovereignty? Institutionalists argue that legal institutions offer a number of desirable functions: they reduce transaction costs, expand the grounds for compromise, monitor compliance, and adjudicate disputes. International judicialisation thus occurs 'when the benefits of reducing future political uncertainty outweigh the "sovereignty costs" of membership."11

These institutionalist assumptions of shared interests are prevalent in scholarship about Africa's international judicialisation. For instance, Charles Jalloh argues that support for the creation of the ICC derived from 'self-interest and historical experiences with untold atrocities', while James Gathii derives regional trade agreements from 'cross-border challenges' and 'co-operation around common resources. ${ }^{12}$

In liberal institutionalist theory, design features reflect state preferences when establishing ICs. Features such as compulsory jurisdiction and private access enable courts to enforce law and regulate bureaucracies and governments; this makes them 'self-binding' from the perspective of state parties. ${ }^{13}$ Self-binding international commitments 'lock in' domestic policies in the face of

\footnotetext{
${ }^{11}$ Andrew Moravscsik, 'The origins of human rights regimes: Democratic delegation in postwar Europe', International Organization 54, 2 (2000), p. 220.

${ }^{12}$ Charles C. Jalloh 'Regionalizing International Criminal Law?', International Criminal Law Review 8 (2008), p. 497; James T. Gathii, African regional trade agreements as legal regimes (Cambridge University Press, Cambridge, 2011), p. xxix.

13 Karen J. Alter, 'Delegating to International Courts: Self-binding vs. Other-binding Delegation', Law and Contemporary Problems 71, 1 (2008), pp. 37-76.
} 
future political uncertainty. ${ }^{14}$ They are motivated by a distrust of future governments ${ }^{15}$ or a need to signal credibility to domestic audiences. ${ }^{16}$ Delegation to ICs thus has domestic sources.

A second research agenda is constructivist. Like institutionalism, this analyses the creation of new legal regimes in distinct stages, advancing different explanations for their design and states' subsequent 'commitment' to (or ratification of) them. ${ }^{17}$ However, design choices do not reflect domestic political considerations. Instead, 'norm entrepreneurs' in civil society create new issue areas and then persuade (liberal) states and international organisations to institutionalise them. In the commitment phase, meanwhile, (authoritarian) states, who initially deny the validity of international norms, ratify treaties and accede to new institutions in order to make 'tactical concessions.' Under civil society pressure, that is, they make 'cosmetic' changes for 'instrumental or strategic' reasons, hoping to avoid 'international isolation.' ${ }^{\text {'18 }}$

Constructivist scholarship on Africa's international judicialisation focuses, similarly, on norm internalisation and the role of NGOs. For instance, Grant and Hamilton see in the many ICC Statute ratifications 'a joint commitment to the norms associated with liberal conceptions of justice', while Rachel Murray highlights NGOS' role in persuading states to ratify the Protocol establishing the African Court on Human and People's Rights. ${ }^{19}$

Both the case studies below demonstrate how these two mainstream theories fail to explain the African creation of international courts. African judicialisation becomes understandable, rather, when seen through the lens of Jean-François Bayart's extraversion.

\footnotetext{
${ }^{14}$ Moravscsik, 'The origins', p. 228.

${ }^{15}$ Ibid; Alter, The new terrain, p. 154.

${ }^{16}$ Beth Simmons and Allison Danner, 'Credible commitments and the International Criminal Court', International Organization 64, 2 (2010), pp. 225-56.

17 Thomas Risse and Kathryn Sikkink, 'The socialization of international human rights norms into domestic practices: Introduction', in Thomas Risse, Kathryn Sikkink and Stephen Ropp (eds), The power of human rights: International norms and domestic change (Cambridge University Press, Cambridge, 1999), pp. 1-38; Thomas Risse and Stephen Ropp, 'Introduction and overview', in Thomas Risse, Stephen Ropp and Kathryn Sikkink (eds), The persistent power of human rights: From commitment to compliance (Cambridge University Press, Cambridge, 2013), pp. 3-25.

${ }^{18}$ Risse and Sikkink, ‘The socialization', pp. 25-28; Risse and Ropp, 'Introduction and overview’, pp. 6-7.

${ }^{19}$ J. Andrew Grant and Spencer Hamilton, 'Norm dynamics and international organisations: South Africa in the African Union and International Criminal Court', Commonwealth and Comparative Politics 54, 2 (2016), p. 171; Rachel Murray, Human rights in Africa: from the OAU to the African Union (Cambridge University Press, Cambridge, 2004), p. 68 .
} 


\section{Legal extraversion}

The concept of extraversion denotes state elites' pursuit and maintenance of relations of dependence with more powerful external actors in order to secure international support. It takes several forms, from manipulation of patron state alliances and alignment with donor policies to discursive and symbolic performances that shape the external representation. ${ }^{20}$ Practices of extraversion derive primarily from a longue durée history of African statehood, whereby difficulties in acquiring domestic rents and resources have turned regimes outwards, towards the international arena. ${ }^{21}$ Over time, they have actively pursued dependence on the international system, their external environment constituting less of a structural constraint than 'a major resource in the process of political centralization and economic accumulation.' ${ }^{22}$ Dependency, on Bayart's view, can thus represent a 'mode of action.' 23

This idea illuminates our case studies in a variety of ways. An orientation towards accumulating resources from the international realm helps us understand why African ruling elites seemingly failed to pursue their national interests during the design of international courts; why they preempted pressure from transnational networks for normative change; why their commitments to new institutions were signalled not to domestic populations; and, lastly, why there was nothing sovereignty-preserving about their concessions. In short, it helps us solve a puzzle that confounds scholars of international courts: the question of why Africa, to a greater extent than other regions, has made so many commitments to the international legal order that are apparently only 'skindeep.' 24

\footnotetext{
${ }^{20}$ Bayart, 'Africa in the world'; Jonathan Fisher, "Image management' and African agency: Ugandan regional diplomacy and donor relations under Museveni' in William Brown and Sophie Harman (eds), African agency in international politics (Routledge, Abingdon, 2013), pp. 97-113; Cédric Jourde, 'The international relations of small neoauthoritarian states: Islamism, warlordism and the framing of stability', International Studies Quarterly 51, 2 (2007), pp. 481-503; Caryn Peiffer and Pierre Englebert, 'Extraversion, Vulnerability to Donors, and Political Liberalization in Africa', African Affairs 111, 444 (2012), pp. 355-78.

${ }^{21}$ Bayart, The state in Africa, p. lvi.

${ }^{22}$ Bayart, 'Africa in the world', p. 219.

${ }^{23}$ Ibid., p. 218.

${ }^{24}$ Romano, 'The shadow zones', p. 99. This point can be illustrated with the example of the ECOWAS Community Court. Although by far the most active of Africa's regional courts, it still confronts 'Herculean challenges' in attempting to enforce judgements, a majority of which remain dead letter. Jerry Ukaigwe, ECOWAS Law (Springer, Cham, 2016),
} 
Methodologically, the notion of extraversion highlights African agency in the international system. Where the interest-oriented and self-binding agency assumed by liberal institutionalists is difficult to find empirically in Africa's international relations, as we shall see below, constructivists struggle to theorise agency by internationally weak, non-liberal states and limit their role to the making of (doomed) tactical concessions. ${ }^{25}$ More generally, realists focus on 'how external actors such as aid donors and great powers old and new have affected a marginalised, victimised and almost politically inert "Africa".,26

Bayart's work challenges such assumptions. Identifying explanatory mechanisms - 'framing' and 'image management' - Cédric Jourde and Jonathan Fisher show how some African elites have succeeded in actively influencing how donors and hegemons see them, in line with 'positive' narratives of international assistance. ${ }^{27}$ In this way, even dominant external actors can become 'sucked into' African struggles over external resources used to pursue internal political agendas. ${ }^{28}$ This is a process that alters both the dominant and the weak party; to maintain resource flows extraverted states actively engage in 'discursive and symbolic performances' that 'shape' the representations that stronger counterparts hold about them. ${ }^{29}$ The notion of extraversion thus build on the Foucauldian insight that resistance resides at 'the very heart of the power relationship ... constantly provoking it. ${ }^{30}$ Ignoring the strategies of 'dominated' African regimes, in short, leads us to fatally misunderstand their international relations.

Extraversion should not, however, be understood as a permanent feature of African politics. Bayart has been criticised, notably, for ahistoricism, treating the deep 'grammar' of extraversion as an all-

p. 99. Illustrating member states' lack of commitment to the court, even its Registry officials are uncertain of how many states have designated organs to oversee implementation - estimates range between three and five of the 15 member countries (interview with Registry officials, Abuja, 1 August 2016).

${ }^{25}$ Risse, Sikkink and Ropp (eds), The power of human rights; 'The socialization'; Risse and Ropp, 'Introduction and overview', p. 15.

${ }^{26}$ William Brown, ‘A question of agency: Africa in international politics', Third World Quarterly 33, 10, p. 1890.

${ }^{27}$ Fisher, 'Image management'; Jourde, 'The international relations'.

${ }^{28}$ Christopher Clapham, Africa in the international system: The politics of state survival (Cambridge University Press, Cambridge, 1996), p. 139.

${ }^{29}$ Jourde, 'The international relations', pp. 484-5.

${ }^{30}$ Michel Foucault, 'The subject and power', in James Faubion (ed.), The essential works of Foucault 1954-1984: Volume III, power (New Press, New York, 2000), p. 342. 
pervasive and unchanging aspect of Africa's 'historicity. ${ }^{31}$ Any such a view obscures historical shifts, such as that associated with the end of the Cold War. Legal extraversion was but one possible strategic response to the many constraints imposed by Africa's international environment; just one of many Bayartian techniques of self-preservation adopted by African ruling regimes after 1989.

This dynamic notion of extraversion illuminates, notably, the variable salience of African nationalism in international relations. As recent backlash against the ICC has helped make clear, this ideology was not simply exhausted by the 1990s, as Karen Alter claims. ${ }^{32}$ But nor, pace William Brown, have nationalist norms been so fundamentally constitutive of African states that they have always been unwilling to relinquish formal legal sovereignty for the sake of aid. ${ }^{33}$ Nationalist discourse was deliberately de-emphasised to serve extraversion in the 1990s. As Celestine Nyamu-Musembi has described, the post-1989 rule of law revival was, 'on the whole,' donor-driven, with international support for justice sector programmes rising six-fold between 1994 and 2002. ${ }^{34}$ For many weak states, this placed a premium on international legitimation as a rule-oflaw respecting state, leading them to pre-empt such donor pressures. The creation of international courts thus allowed African states to redefine their international identities.

By contrast, in the late 1970s and early 1980s, African states produced one of the world's most idiosyncratic human rights documents: the 1981 African Charter of Human and People's Rights. The Charter's particularities - which included the 'right to development', 'peoples rights' and even duties towards the 'national community' and family - were intended to signal a 'revanchist' African dissatisfaction with the post-war international order. ${ }^{35}$ Sovereignty had been carefully protected and global scripts ignored. The contrast between such self-assertive stances and those of the next decade could hardly be starker.

\footnotetext{
${ }^{31}$ E.g. Thomas Young, 'The state and politics in Africa', Journal of Southern African Studies 25, 1 (1999), p. 151. Bayart, meanwhile, protests that he only seeks to analyse a historically contingent form of 'governmentality': a 'complex strategic situation in a given society'. Bayart, 'Fait missionnaire et politique du ventre: une lecture foucaldienne', Le Fait Missionnaire 6 (1998) pp. 14-5.

${ }^{32}$ Alter, The new terrain, p. 136-7.

${ }^{33}$ William Brown, 'Sovereignty matters: Africa, donors, and the aid relationship', African Affairs 112, 447 (2013), pp. $270,281$.

${ }^{34}$ Celestine Nyamu-Musembi, 'Ruling out gender equality? The post-Cold War rule of law agenda in sub-Saharan Africa' in Third World Quarterly 27, 7 (2006), p. 1194.

${ }^{35}$ Nathaniel Rubner, The origins of the 1981 African Charter on Human and Peoples' Rights (University of Cambridge, unpublished PhD dissertation, 2011), pp. 180, 245-302. Contrast Murray, Human rights in Africa, pp. 22-3.
} 


\section{Judicialisation as extraversion: the ICC and the SADC Tribunal}

The following case studies examine how the ruling elites in Kenya and Zimbabwe supported the creation of the ICC and the SADC Tribunal. They focus on the design of, and initial commitment to, these two international courts, as this is where the explanatory power of the two mainstream theories purports to lie. The studies analyse court initiation, rule negotiation, design features, and treaty ratification, arguing that the creation of these courts was less the result of liberal state agency or civil society pressure and more the outcome of a set of extraverted practices.

Kenyan support for the ICC

Almost two-thirds of African states have joined the ICC. 21 did so during the first four years after the Rome Conference that established the ICC. The early African support for the establishment of the ICC is well-documented, yet poorly explained. ${ }^{36}$ This case study analyses support by the Moi and Kibaki regimes in Kenya, investigating first design inputs and thereafter Statute ratification.

\section{Court design}

Inter-state negotiations of the ICC treaty took place in four forums: the 1995 Ad Hoc Committee on the Establishment of an International Criminal Court provided for the first informal negotiations on a draft ICC statute prepared by the International Law Commission. Negotiations continued in the Preparatory Committee, which met at the UN in New York between 1996 and 1998. ${ }^{37}$ This work

\footnotetext{
${ }^{36}$ Charles C. Jalloh, 'Regionalizing'; Max du Plessis, 'The International Criminal Court that Africa wants' (Institute for Security Studies, Pretoria, 2010).

${ }^{37}$ No summary records of the Ad Hoc and Preparatory Committee meetings exist, but see Christopher Keith Hall 'The first two sessions of the UN Preparatory Committee on the Establishment of an International Criminal Court', The American Journal of International Law 91, 1 (1997), pp. 177-87, and 'The third and fourth sessions of the UN
} 
culminated in the 1998 Rome Conference, where 120 states formally adopted the ICC Statute. Afterwards a Preparatory Commission tackled outstanding issues. Through advocacy for technical assistance and financial support, African states, including Kenya, inserted themselves in this drafting process as dependent participants.

The work of the Ad Hoc and Preparatory Committees was marked by 'limited participation' of delegations from developing countries. ${ }^{38} \mathrm{Du}$ Plessis argues that African states 'contributed extensively to the preparations leading up to, during and after' the Rome Conference, ${ }^{39}$ but observers in Preparatory Committee noted that African countries participated actively only in the final session. ${ }^{40}$ According to African members, the obstacle was financial.

African states addressed the 'continuing absence of a large number of delegations, particularly from developing countries' and advocated the establishment of trust funds to finance the participation of the least developed countries in the design process. ${ }^{41}$ The first fund was set up in late 1996, but 1997 saw little participation from developing countries and hence little design input by these states. ${ }^{42}$ According to South Africa, more developing states would have participated if the fund had provided for delegates' cost of living expenses during meetings. ${ }^{43}$

African states met regionally to explore common positions on the ICC. SADC countries developed a Common Statement of support for an independent ICC, while 25 African states met in Dakar. ${ }^{44}$

Preparatory Committee on the Establishment of an International Criminal Court', The American Journal of International Law, 92, 1 (1998), pp. 124-33.

${ }^{38}$ Hall, 'The first two sessions', p. 186.

${ }^{39}$ Max du Plessis, 'The International Criminal Court', p. 6.

${ }^{40}$ Christopher Keith Hall 'The sixth session of the UN Preparatory Committee on the Establishment of an International Criminal Court', The American Journal of International Law 92, 2 (1997), p. 556.

${ }^{41}$ Statement by Kenya, UN Doc. A/C.6/51/SR.27 (29 October 1996). See statements from Cote D'Ivoire, Ethiopia, Ghana, Kenya, Lesotho, Madagascar, Malawi, Nigeria, South Africa, Tanzania and Uganda in UN Docs A/C.6/51/SR.27 (29 October 1996), A/C.6/51/SR.29 (1 November 1996), A/C.6/52/SR.11 (21 October 1997), A/C.6/52/SR.12 (23 October 1997), A/C.6/52/SR.13 (23 October 1997), A/C.6/53/SR.9 (21 October 1998), A/C.6/53/SR.10 (21 October 1998), A/C.6/53/SR.11 (22 October 1998), A/C.6/53/SR.12 (22 October 1998), A/C.6/54/SR.14 (22 October 1999).

${ }^{42}$ UN Doc. A/Res/51/207 (17 December 1996).

${ }^{43}$ Statement by South Africa, UN Doc. A/C.6/52/SR.11 (21 October 1997).

44 Sivu Maqungo, 'The establishment of the International Criminal Court: SADC's participation in the negotiations', African Security Review 9, 1 (2000), n.p.; 'Dakar declaration for the establishment of the International Criminal Court in 1998'. 
These meetings aimed to create consistency in negotiating positions, but African countries joined different alliances in Rome. ${ }^{45}$

The Rome Conference took place in mid-1998, bringing 160 state delegations together with 30 international bodies and 138 NGOs. At the Conference, state delegations split into informal groupings, such as the Non-Aligned Movement and the like-minded group. The conference was dominated by the like-minded states, a cluster of more than 60 delegations that were supportive of establishing the ICC and committed to particular design features that were incorporated into the Statute: jurisdiction over genocide, crimes against humanity and war crimes, the elimination of a Security Council veto on prosecutions, an independent prosecutor with proprio motu authority, and the prohibition of reservations to the Statute. ${ }^{46}$

Kenya preferred, along with most African states, the Non-Aligned caucus, advocating minimising Security Council control over the ICC. ${ }^{47}$ Although the ICC's proprio motu indictment of Kenyan government officials in 2010 imposed an accountability process, there is no indication that the Moi administration intended to 'self-bind' or 'lock in' future governments. In fact, it opposed prosecutorial proprio motu powers. ${ }^{48}$ Instead, Kenya 'called upon the international community to assist developing countries in their efforts to strengthen ... their justice administration systems, including the courts. ${ }^{49}$

Delegates from 52 developing countries participated in the Rome Conference under the auspices of the trust fund. Using trust funds to facilitate participation in multilateral conferences was not

\footnotetext{
${ }^{45}$ Only six SADC countries joined the like-minded group, although the group's position corresponded to the SADC declaration. The 'like-minded' African states were Benin, Burkina Faso, Burundi, Congo (Brazzaville), Gabon, Ghana, Lesotho, Malawi, Namibia, Senegal, Sierra Leone, South Africa, Swaziland, and Zambia. See William Schabas, The International Criminal Court: A commentary on the Rome Statute (Oxford University Press, Oxford, 2010), p. $22 \mathrm{n}$. 170.

${ }^{46}$ William Schabas, An introduction to the International Criminal Court (Cambridge University Press, Cambridge, 2001), pp. 15-16. Proprio motu authority permits the Prosecutor to initiate investigations, subject to Pre-Trial Chamber approval.

${ }^{47}$ United Nations Diplomatic Conference of Plenipotentiaries on the Establishment of an International Criminal Court 'Official records, volume II. Summary records of the plenary meetings and of the meetings of the Committee of the Whole.' UN Doc. A/CONF.183/13 (Vol. II) (United Nations, New York, 1998), pp. 77, 208.

${ }^{48}$ Ibid., pp. 199-200.

${ }^{49}$ Ibid., p. 77.
} 
novel, but the practice was 'new to conferences convened to codify public international law.' 50 Given that negotiations are relational, African countries' continuous calls for monetary support may have weakened their bargaining positions.

Constructivist scholarship highlights the role of NGOs during the Rome Conference. ${ }^{51}$ However, the 134 participating NGOs were overwhelmingly based in Europe and North America; only 14 were African. ${ }^{52}$ These include a Kenyan legal association, which, however, does not appear to have influenced Kenya's design decisions. In contrast, western-based NGOs present at the New York and Rome sessions informed 'like-minded' positions. ${ }^{53}$

After the Conference, African states continued their extraverted discursive and symbolic performances: while urging the signing and ratification of the Rome Statute, they called for financial assistance to developing countries to participate in Commission meetings. Kenya even encouraged international NGOs to 'extend their support' so that 'political, moral and social will could be mobilised. ${ }^{54}$ Throughout the drafting process, African states thus constructed their participation as dependent on charity by wealthier states. This representation surely did not strengthen their negotiating positions; but it did position them at the forefront of the global fight against impunity.

\section{Treaty ratification}

\footnotetext{
${ }^{50}$ Roy S. Lee 'Introduction: The Rome Conference and its contributions to international law', in Roy S.K. Lee (ed.), The International Criminal Court: The making of the Rome Statute: Issues, negotiations and results (Kluwer Law International, The Hague, 1999), p. 9.

${ }^{51}$ Håkon Friman 'The International Criminal Court: Negotiations and key issues', African Security Review 8, 6 (1999), pp. 3-14; Benjamin N. Schiff, Building the International Criminal Court (Cambridge University Press, Cambridge, 2008), ch. 5 .

52 See 'Final Act of the United Nations Diplomatic Conference of Plenipotentiaries on the Establishment of an International Criminal Court' UN Doc. A/CONF.183/10, Annex IV, 'List of non-governmental organizations represented at the conference by an observer.'

${ }^{53}$ Hall, 'The first two sessions' and 'The third and fourth sessions'; Schiff, Building the International Criminal Court, ch. 5 .

${ }^{54}$ Statement by Kenya, UN Doc. A/C.6/54/SR.14 (22 October 1999).
} 
Kenya, now ruled by Mwai Kibaki, ratified the Statute in March 2005, based on a 'unanimous decision' by the cabinet. ${ }^{55}$ As in many other African countries, the decision to commit to the ICC was purely an executive matter, which was not put to parliament. ${ }^{56}$ When asked in 2011 why Kenya ratified the Rome Statute, the then Minister of Justice and Constitutional Affairs, Mutula Kilonzo, explained,

we are an outward reaching country, not inwards [looking]. We still think we can learn from others, notwithstanding that there can be unforeseen consequences, but we are a country that looks far beyond our borders. $^{57}$

Even a cabinet minister (and lawyer by profession) in charge of unprecedented judicial overhaul did not explain Kenya's commitment to the ICC in terms of domestic factors.

Kenya became the $27^{\text {th }}$ African ICC state party, because foot-dragging 'aimed at buying time' to 'put off pressure' by the US to sign a bilateral agreement to not surrender Kenyan and US citizens to the ICC. ${ }^{58}$ The Kibaki regime resisted 'being arm and neck twisted by the big brother' into signing the agreement ${ }^{59}$ and therefore lost military aid and economic support worth USD 8.76 million in $2005 .{ }^{60}$ The decision to delay ratification had tangible benefits, as Kenya avoided a US penalty in 2004. Liberal institutionalist theory may explain this delay, but cannot account for the decision to ratify, given the costs of doing so.

Civil society interest in Kenyan ratification emerged during 2004, but was confined to a few organisations. Only after the 2008 post-election crisis did MPs and civil society become interested

\footnotetext{
${ }^{55}$ Hansard (Parliament of the Republic of Kenya), 11 November 2009, p. 3706.

${ }^{56}$ Hansard (Parliament of the Republic of Kenya), 27 April 2005, p. 1000.

${ }^{57}$ Interview with Mutula Kilonzo, Nairobi, 9 May 2011.

58 Thita Mwangi, Director of Political Affairs in the Ministry of Foreign Affairs, quoted in 'The forum on the International Criminal Court and the African Court on Human and Peoples' Rights' (Kenya National Commission on Human Rights, Nairobi, 2004), p. 25.

${ }^{59}$ Peter ole Nkuraiya, quoted in Mucheru Kelvin and Judy Komen, 'Kenya under pressure not to sign ICC pact', The East African Standard, 21 July 2003 (9 September 2013).

60 'Countries opposed to signing a US Bilateral Immunity Agreement (BIA): US aid lost in FY04 \& FY05 and threatened in FY06' (Coalition for the ICC, New York, 2006), http://www.iccnow.org/documents/CountriesOpposedBIA_AidLoss_current.pdf (24 May 2016).
} 
in the ICC. ${ }^{61}$ As predicted by constructivists, foreign NGOs got involved, but this was three years after ratification.

Kenyan support before, during and after the Rome Conference did not meet liberal institutionalist or constructivist expectations, but can be understood as extraverted agency. International deliberation centred on material assistance and 'image management', rather than on specific design features that matched national interests or spoke to civil society concerns. Participation and ratification were not communicated domestically, thus hardly providing a credible commitment or a tactical concession. Kenyan participation in the negotiations was discursively produced as relying on the UN trust funds, ${ }^{62}$ thus pulling like-minded states into the project as financial sponsors. Committed to the Statute's rapid entry into force, like-minded states realized they 'would need to allocate substantial resources to assist smaller states in the process' of promoting universal participation. ${ }^{63}$ As a result, Canada, Norway, the EU and others funded the global NGO ratification campaign.

\section{Zimbabwean support for the SADC Tribunal}

The SADC Tribunal confounds institutionalist and constructivist expectations. Our analysis of the design phase largely takes SADC states as a group, whilst our analysis of ratification (when information about particular state strategies becomes more readily available) focuses on Zimbabwe more specifically.

\section{Court design}

\footnotetext{
${ }^{61}$ See, e.g., Hansard (Parliament of the Republic of Kenya) 27 August 2009 and 11 November 2009.

${ }^{62}$ Statement by Kenya to the Sixth Committee, UN doc A/C.6/51/SR.27 (29 October 1996).

${ }^{63}$ Joanne Lee 'Enough rope: The role of Minervian actors in establishing the International Criminal Court', Yves Tiberghien (ed.), Leadership in global institution building: Minerva's rule (Palgrave, Basingstoke, 2013), p. 225.
} 
SADC was founded in August 1992, during the post-apartheid transition. It replaced the Southern African Development Co-ordination Conference (SADCC), established in 1980. This organisation's main achievement had been to divert trade from areas affected by apartheid 'de-stabilisation. ${ }^{94}$ Its institutions were decentralised and sovereignty-preserving, with each member state responsible for co-ordinating development projects in a particular area. Disputes which could not be 'settled by negotiation, conciliation or other means' were to be 'referred to the Summit', comprised of Heads of State. ${ }^{65}$ No court was envisaged. These were idiosyncratic arrangements: the first systematic rejection of orthodox integration theory by any group of Third World nations. ${ }^{66}$ Yet during the Cold War donors did not endorse global scripts. They even praised SADCC. In 1988 World Bank VicePresident for Africa, Edward Jaycox, labelled it a 'functioning example of how regional cooperation in Africa might work', whilst British Minister for Overseas Development, Chris Patten, declared that to 'support SADCC is to support success. ${ }^{67}$

After the Cold War and apartheid, however, senior SADCC figures immediately understood that new and more prescriptive donor agendas needed to be catered to. Foreign agencies had provided over 90 per cent of the organisation's funding. ${ }^{68}$ Sweden was the leading donor and Nordic aid (overwhelmingly dedicated to anti-apartheid) had exceeded inflow of commercial capital. ${ }^{69}$ By 1990 threats to this revenue were obvious. ${ }^{70}$ SADCC's Zimbabwean Executive Secretary, Simba Makoni, spoke candidly of why extraversion tactics might be required:

\footnotetext{
${ }^{64}$ See Richard Gibb, 'The effect on the countries of SADCC of economic sanctions against the Republic of South Africa', Transactions of the Institute of British Geographers 12, 4 (1987), pp. 398-412.

65 Rose Mtengeti-Migiro, Institutional arrangements for economic integration in Eastern and Southern Africa (Konstanz, Hartung-Gorre, 1992), pp. 61-2.

${ }^{66}$ Richard Gibb, 'The relevance of the European approach to regional economic integration in post-apartheid southern Africa', in Anthony Lemon (ed.), The geography of change in South Africa (Wiley, Chichester, 1995), pp. 223-4.

${ }^{67}$ Edward Ramsamy, 'South Africa and SADC(C): a critical evaluation of future development scenarios', in Lemon (ed.), The geography of change, p. 201.

${ }^{68}$ Ibid., p. 202.

${ }^{69}$ Bertil Odén, 'Factors affecting the flows of external capital to post-apartheid southern Africa', in Bertil Odén (ed), Southern Africa after apartheid: Regional integration and external resources (Nordiska Afrikainstitut, Uppsala, 1993), pp. 226-7.
}

${ }^{70}$ Arne Tostensen et al., The Nordic/SADCC initiative (Chr. Michelsen Institute, Bergen, 1990), pp. 33-4. 
support from the international community has not really come to us on our own account. It has come to us as sympathy support against apartheid ... So while one appreciates the amount that we have been receiving, the spirit behind the figures is not a very comforting one, because if it remains the basis for that support, when apartheid goes, the so will the funds go with it. ${ }^{71}$

Radical 'economic liberation' rhetoric retreated along with Scandinavian aid. ${ }^{72}$ Tracking the changed preferences of its new principal donors, led by the European Economic Community, SADCC soon endorsed more orthodox forms of economic integration as cures for Africa's economic woes. $^{73}$

It was not immediately obvious, however, that any revamped organisation would include an equivalent of the European Court of Justice (ECJ). In 1991, SADCC officials preferred an 'arbitration tribunal or a committee', the two alternatives then being considered for the General Agreement on Tariffs and Trade (GATT). ${ }^{74}$ This position changed dramatically at SADCC's 1992 Consultative Conference. The Conference's Theme Document, partly drafted by European experts, proposed an ECJ-style institution which even ordinary citizens could approach: a mechanism of 'mediation and arbitration, to which all agents of integration - governments, business, civil associations and individuals - can seek justice. ${ }^{75}$ The extraversion strategies behind this recommendation were alluded to in the Document itself. Whilst 'international political and material support for SADCC' had been 'predicated on the anti-apartheid struggle', future external assistance

\footnotetext{
${ }^{71}$ In Rasmsamy, 'South Africa and SADC(C)', p. 202.

${ }^{72}$ Compare reports from its first and last major meetings: SADCC, Southern Africa: Towards economic liberation (Collings, London, 1981); SADCC, Towards economic integration: Proceedings of the Annual Consultative Conference held in Maputo (Gaborone, SADCC, 1992).

${ }^{73}$ SADCC, SADCC Annual report, July 1990-June 1991 (Maputo, SADCC, 1992), pp. 8-9; Réal Lavergne and Koffie Daddieh, 'Donor perspectives', in Réal Lavergne (ed.), Regional integration and co-operation in West Africa (Ottowa, IDRC, 1997), p. 105.

${ }^{74}$ Mtengeti-Migiro, Institutional arrangements, p.153, n.17; Francesco Duina and Tobias Lenz, 'Regionalism and diffusion revisited: From final design towards stages of decision-making', Review of International Studies 42, 4 (2016), pp. 792-3.

75 Tobias Lenz, 'Spurred emulation: the EU and regional integration in Mercosur and SADC', West European Politics 35, 1 (2012), p. 165; Duina and Lenz, 'Regionalism and diffusion revisited', pp. 792-3.
} 
would depend upon 'policy reforms'. ${ }^{76}$ European donors stressed that aid would become conditional on 'necessary political decisions' and 'renouncing part of ... sovereignty., 77

Heads of State swiftly pre-empted conditionality, claiming to have 'draw[n] important lessons' from the European Economic Community's Maastricht Summit. ${ }^{78}$ Six months later, the 1992 Windhoek Treaty relaunched SADCC as SADC. A regional Tribunal would be among 'the central intergovernmental organs' of the new Community, despite there having been effectively no regional debate about whether such court promoted inter-regional trade. ${ }^{79}$ Even within South Africa's ANC, which was already universally recognised as the most powerful force in SADC, debate about the various options had 'scarcely even begun'. ${ }^{80}$ Indeed, as Lenz notes, 'when the decision was taken to establish a Tribunal with the Windhoek Treaty, no real discussion on the costs and benefits of different options had taken place at the regional level. ${ }^{, 81}$ Strategic explanations for legal institutions clearly cannot explain this outcome.

The Zimbabwean Justice Minister has recently argued that post-1992 negotiations left the SADC Tribunal without the 'DNA imprint' of member states. ${ }^{82}$ The evidence largely supports his assertion. South Africa was the first and only state to develop a distinctive public position. In October 1993, the ANC called for a dedicated 'Regional Court of Human Rights' and even a 'Regional Mutual Security structure, to enforce and protect human rights. ${ }^{93}$ Six months later, however, when the new post-apartheid government had finally officially joined SADC, the ANC's desire to protect its new Constitutional Court caused it to become suspicious of all such

\footnotetext{
${ }^{76}$ SADCC, Towards Economic Integration, p. 19.

${ }^{77}$ Ibid., pp. 137, 145.

${ }^{78}$ Ibid., Introduction, p. 50.

${ }^{79}$ Duina and Lenz, 'Regionalism and diffusion revisited', p. 793.

${ }^{80}$ Robert Davies, 'Emerging South African perspectives on regional cooperation and integration after apartheid', in Odén (ed), Southern Africa after apartheid, p. 83.

${ }^{81}$ Lenz, 'Spurred emulation', p. 165.

${ }^{82}$ Caesar Zvayi, 'Zim wants SADC Tribunal rulings nullified', The Herald (19 May 2011).

${ }^{83}$ African National Congress Department of International Affairs, 'Foreign policy in a new democratic South Africa, a discussion paper' (African National Congress, Johannesburg, 1993).
} 
institutions. ${ }^{84}$ Three years later, meanwhile, during the first discussions over the Tribunal Protocol, SADC states rejected calls by two legal experts - including a judge from the ECJ - for 'an embryonic form of human rights jurisdiction. ${ }^{95}$ The final Protocol, signed in 2000, created an institution more like the ECJ itself than a human rights court. It established a court with private access rights, exclusive competence to constitutional review, and a preliminary rulings procedure lifted entirely from the European Union's Treaty of Rome. ${ }^{86}$ Tribunal officials confirm that the Luxembourg Court remains the Tribunal's primary point of reference. ${ }^{87}$

The creation of Tribunal with such powers is difficult to explain by referencing member state preferences. And yet, despite the presence of an ECJ legal expert, there is no evidence that it was the product of aid conditionality or direct EU pressures. ${ }^{88}$ Nor did it reflect the preferences of regional NGOs and norm entrepreneurs. Between 1994 and 1997, at the height of liberal postapartheid optimism, there had indeed been considerable mobilisation around the question of a court for SADC. Zimbabwean lawyers and human rights organisations were central to these networks, as they are today - with involvement from soon-to-be leading opposition politicians such as Welshman Ncube and David Coltart. ${ }^{89}$ In 1996, after 18 months of internal consultations and meetings with ministers and SADC officials, these NGOS produced a draft human rights charter for the region, which was to be applied by a dedicated Human Rights Court. ${ }^{90}$ As already noted, however member states rejected this option, preferring instead to emulate the ECJ.

\footnotetext{
${ }^{84}$ Lenz, 'Spurred emulation', p. 166.

${ }^{85}$ Frans Viljoen, 'The realisation of human rights in Africa through sub-regional institutions', in Abdulqawi Yusuf (ed.), African yearbook of international law (Brill, Leiden, 1999), p. 200; Merran Hulse and Anna van der Vleuten, 'Agent run amuck: the SADC Tribunal and governance transfer roll-back', in Tanja Börzel and Vera van Hüllen (eds), Governance transfer by regional organizations: patching together a global script (Palgrave Macmillan, New York, 2015), p. 89.

${ }^{86}$ Lenz, 'Spurred emulation', p. 167.

${ }^{87}$ Interview with Charles Mkandariwe, SADC Tribunal Registrar, Windhoek, 22 August 2011; Laurie Nathan, Community of Insecurity: SADC's Struggle for Peace and Security in Southern Africa (Farnham, Ashgate, 2012), p. 113.

${ }^{88}$ Ibid., p. 163.

${ }^{89}$ Interviews with Makanatsa Makonese, SADC Lawyers’ Association, Pretoria, 30 April 2012, and Lloyd Kuveya, Southern African Litigation Centre, Johannesburg, 3 May 2012; Tambayi Nyika, 'A blow for human rights', West Africa, 13-19 May 1996, p. 743.

${ }^{90}$ Ibid.; Viljoen, 'The realisation of human rights', p. 201.
} 
One inevitable consequence of these extraversion strategies was shoddy statecraft. The 1992 Windhoek Treaty was notable for both its 'poor drafting' and eager repeating of the 'global script' of human rights. ${ }^{91}$ Despite states being opposed a dedicated human rights court, they nonetheless added 21 direct and indirect references to such rights to the new Community's Protocols. ${ }^{92}$ Even before judges began interpreting these references in 'activist' ways, regional NGOs had noted how they allowed for human rights litigation. ${ }^{93}$ As argued by Judge Ariranga Pillay, once President of the court, regional leaders had simply failed to protect their interests when drafting the Treaty. They never 'process[ed] all the implications of a SADC Tribunal.' Their goal for the institution was simply 'to get funds from the European Union and others' by giving-off 'all the right buzz words, you know, "democracy, rule of law, human rights". 94 In a classic case of 'image management', supposedly sacrosanct formal sovereignty had been sacrificed on the altar of extraversion. ${ }^{95}$

\section{Treaty ratification}

Neither civil society mobilisation nor domestic political calculation account for ratification of the Tribunal. As described below, the process was lengthy and haphazard. This was perhaps unsurprising, however, given SADC states' reluctance in the mid-1990s to actually implement the Windhoek reforms; post-apartheid extraversion having (temporarily) constrained donors' once 'barely concealed eagerness' to withdraw funding. ${ }^{96}$ Institutional reform only returned to the SADC agenda in 1999, thanks to the contingencies of high politics. Eager to intervene in the Democratic

\footnotetext{
${ }^{91}$ Derek Matyszak, 'The dissolution of the SADC Tribunal' (Research and Advocacy Unit, Harare, 2011), p. 3, n. 22; Frederick Cowell, 'The death of the Southern African Development Community Tribunal's human rights jurisdiction', Human Rights Law Review 13, 1 (2013), p. 156.

${ }^{92}$ Cowell, ‘The Death', p. 155.

${ }^{93}$ Interviews, Zimbabwean human rights activists, Harare and Johannesburg, April-May 2012. Tazorora Musarurwa, 'Human rights, SADC and the SADC Tribunal', SADC Tribunal Review 1 (2010), p. 11; Hulse and van der Vleuten, 'Agent run amuck', p. 92.

${ }^{94}$ In Sean Christie, 'Killed off by 'kings and potentates', Mail and Guardian, 19 August 2011.

${ }^{95}$ Contrast Brown, 'Sovereignty matters'.

${ }^{96}$ Davies, 'Emerging South African perspectives', p. 184.
} 
Republic of Congo, Zimbabwe's President Mugabe had hoped to detach the SADC's Organ on Politics, Defence and Security Co-operation from the rest of the organization. ${ }^{97}$ The Summit defused the tensions this created by reviewing the Organ's role, but only as an 'integral part of the SADC. ${ }^{98}$

This unplanned reopening of the SADC 'reform debate' amounted to a dramatic 'volte face', one only made possible by the 'highly personalized' nature of foreign policy making in the region. ${ }^{99}$ It allowed donors and reformers in the Secretariat a fresh opportunity to advocate centralised institutions. ${ }^{100}$ A number of bilateral donors, critical of SADC's inefficiency, eventually started withdrawing aid. ${ }^{101}$ European Commission contributions now easily surpassed all others, including those of member states. It soon decided to continue its support, but resolved inter alia to 'monitor the implementation of SADC protocols and [...] the Establishment of a SADC Tribunal.' ${ }^{102}$ It was in this context that the drafters of the new Tribunal Protocol (signed in 2000) began worrying 'they might never get the nine ratifications needed to get the Protocol binding.' 103 Only Botswana had complied. ${ }^{104}$ Without NGO pressures, these drafters produced an Amendment Treaty circumventing ratification. Although SADC Ministers agreed there was now 'no further requirement for individual member states to ratify the Protocol', Namibia, Mauritius and Lesotho somehow did so nonetheless; 'dutifully complying' with a 'redundant formality.' 105 Ratifying SADC states, in short, neither responded to civil society pressures nor signalled 'credible commitments' to their populations.

\footnotetext{
${ }^{97}$ Nathan, Community of insecurity, p. 42.

${ }^{98}$ Peter Meyns, 'Strengthening regional institutions - Politics and governance in the SADC region', in Dirk Hanshom et al. (eds), Monitoring regional integration in Southern Africa - Yearbook volume 1 (Konrad-Adenauer-Stiftung, Windhoek, 2001), p. 77.

${ }^{99}$ Ibid., pp. 76-7.

${ }^{100}$ See Jan Isaksen and Elling Tjønneland, Assessing the restructuring of SADC - Positions, policies and progress (Chr. Michelsen Institute, Bergen, 2001), p. 4.

${ }^{101}$ Elling Tjønneland, SADC and Donors - Ideals and Practices (Gaborone, BIDPA, 2006), pp. 18-20.

102 Ibid.; Gabriel Oosthuizen, The Southern African Development Community: the organisation, its policies and prospects (Midrand, Institute for Global Dialogue, 2006), p. 181.

${ }^{103}$ Hulse and van der Vleuten, 'Agent run amuck', p. 89.

${ }^{104}$ Compare Ibid. with Jan Isaksen, Restructuring SADC - Progress and Problems (Bergen, Chr. Michelsen Institute, 2002), p. 82.

${ }^{105}$ Matyszak, 'The dissolution', p. 11; Hulse and van der Vleuten, ‘Agent run amuck', p. 89.
} 
Zimbabwe's (non-)ratification is perhaps even more striking in this respect. In 2008, famously, it was defeated in Campbell $v$ Republic of Zimbabwe; white farmers successfully using the Tribunal to challenge the expropriation of their land. ${ }^{106} \mathrm{EU}$ donors consistently covered most Tribunal costs, with member states not even paying for necessary furniture. ${ }^{107}$ Both before and after Campbell, these donors also arranged visits for Tribunal judges to numerous international courts. ${ }^{108}$ Soon afterwards officials from leading liberal NGOs tried to persuade the Zimbabwean farmers to drop Campbell, convinced the Tribunal's judges would inevitably adjudicate using international rule-oflaw standards. This, they believed, would be the end of the court. ${ }^{109}$

These efforts failed. ZANU-PF's humiliating defeat in Campbell saw it successfully orchestrate backlash against the Tribunal. But it did so in ways revealing failures to adopt the 'tactical' approach towards ratification anticipated by the mainstream theories. Immediately after Campbell, Ambassador to Namibia, Chipo Zindoga, declared that 'We cannot walk out from our own organ ... Zimbabwe, as a member of SADC, was instrumental in the formation of the Tribunal. ${ }^{110}$ The next year, Justice Minister Patrick Chinamasa claimed that Zimbabwe had in fact never been properly subject to its jurisdiction. He argued that the Tribunal Protocol drafters had illegally circumvented the need for ratifications. ${ }^{111}$ This was a confusing intervention: ZANU-PF had apparently now defended itself in a court which it believed illegally constituted. Indeed, it had even sent a judge, Antonina Guvava, to that same court. ${ }^{112}$ None of this suggested a 'tactical' approach to ratification, but was symptomatic of a wider regional lack of enthusiasm for the SADC Tribunal. The Tribunal was intended to signal rule-of-law commitments to international actors.

\footnotetext{
${ }^{106}$ For background see Peter Brett, 'Cause lawyers sans frontières: juristes sud-africains et judiciarisation du politique en Afrique australe.' Politique Africaine 138, 2 (2015), pp. 93-113.

${ }^{107}$ Oostehuizen, The Southern African Development Community, p. 355, n.171; Hulse and van der Vleuten, 'Agent run amuck', p. 90.

${ }^{108}$ Interview with Charles Mkandariwe, SADC Tribunal Registrar, Windhoek, 22 August 2011; Hulse and van der Vleuten, 'Agent run amuck', pp. 92-3.

${ }^{109}$ Interview with Lloyd Kuveya, Southern African Litigation Centre, Johannesburg, 3 May 2012.

${ }^{110}$ In Nathan, Community of Insecurity, p. 113.

${ }^{111}$ See Matyszak, 'The dissolution', pp. 7-9.

${ }^{112}$ Michelo Hansungule, 'The suspension of the SADC Tribunal', Strategic Review for Southern Africa 35, 1 (2013), p. 137.
} 


\section{Conclusion}

Over the last two decades, the largest and least investigated changes in the international judiciary have occurred in Africa. States have created a new international judicial infrastructure to enforce rules pertaining to a wide range of activities, from trade and investments to governance and conflict-related atrocity. The fact of Africa's international judicialisation, however, has not been matched by an understanding of the factors that drove it. Commentators now regularly record their puzzlement with how African states have interacted with international law and courts.

Scholars note the signing of 'bizarre' bilateral investment treaties between countries with effectively no economic relations (such as Sudan and Zambia), and they concede, obliquely, that new theories may be needed for "some regions." 113 The perpetual under-funding and underutilization of regional courts is noted by almost everyone, begging the question of why these institutions were established. ${ }^{114}$ Whilst Tiyanjana Maluwa observes how AU treaties - unlike their UN equivalents - are often unratified, despite African states' greater input into their drafting. ${ }^{115}$

The present analysis of 'legal extraversion' suggests a general method for explaining such empirical puzzles. Indeed, the politics of Africa's international law is bewildering only insofar as analysis is informed by the assumptions of the mainstream paradigms. As this article demonstrates, in two cases with a most likely theoretical fit, these assumptions cannot be justified empirically. In neither the case of Kenya and the ICC nor of Zimbabwe and the SADC Tribunal was African support for the creation of an IC explained by external coercion or 'tactical concessions' to normative persuasion: African IC support during the design and ratification phases took place in the absence of donor conditionality, value entrepreneurism, and NGO pressure. Yet institutionalists would be wrong to conclude that 'externally oriented explanations have attracted far more attention

\footnotetext{
${ }^{113}$ Beth Simmons, Zachary Elkins and Andrew Guzman, 'Competing for capital: The diffusion of bilateral investment treaties, 1960-2000’, International Organization 60, 4 (2006), p. 819.

114 James T. Gathii, 'The under-appreciated jurisprudence', p. 46; Abdulqawi A. Yusuf, 'The emergence of judicial institutions for inter-state dispute settlement in Africa: A brief survey', African yearbook of international law 19, 1 (2011), pp 279-94.

115 Tiyanjana Maluwa, 'Ratification of African Union treaties by member states: Law, policy and practice', Melbourne Journal of International Law 13, 2 (2012), p. 12.
} 
than they deserve'116 and to assume instead that an interest-driven domestic political calculus must take priority: Kenya and Zimbabwe did not attempt to give the ICC and the SADC Tribunal a national imprint and they certainly did not aim to self-bind. The governments of Mugabe and Kibaki mobilised backlash against the two ICs when their activities were constrained for the first time.

African states' support for IC creation can be understood as driven by deliberate strategies to manage their image and thereby obtain rents from the international arena. Thus, Africa became the new 'frontier' 117 for international law, and particularly international criminal law, as a result of efforts by state elites to forge new external relationships within the context of the post-Cold War rule-of-law revival.

Our argument is not without contemporary political implications. Although our explanation focuses on the rise, not demise, of ICs in Africa, it helps illuminate the current backlash on the continent. ${ }^{118}$ Today's dramatic revolt against ICs by state elites represents neither a departure from a cost-benefit calculus or a rejection of previously internalised values. It is only explicable once one has fully grasped the strategic background behind African states' numerous 'skin-deep' commitments to new international legal institutions in the 1990s and early 2000s. More than a newfound quest for impunity, contemporary de-judicialisation forms part of a long-term re-framing of African state identities in the international system.

\footnotetext{
${ }^{116}$ Nielsen and Simmons, 'Rewards for ratification', p. 206.

${ }^{117}$ Daniel C. Bach, 'Africa in international relations: The frontier as concept and metaphor', South African Journal of International Affairs 20, 1 (2013), pp. 1-22.

118 Peter Brett and Line Engbo Gissel, 'The African backlash against international law', paper presented at African Studies Association UK Biennial Conference, 8 September 2016.
} 